\title{
Tumor Necrosis Factor Receptor Superfamily Member 5
}

National Cancer Institute

\section{Source}

National Cancer Institute. Tumor Necrosis Factor Receptor Superfamily Member 5. NCI

Thesaurus. Code C17281.

Tumor necrosis factor receptor superfamily member 5 (277 aa, $\sim 31 \mathrm{kDa}$ ) is encoded by the human CD40 gene. This protein is involved in the positive regulation of immunoglobulin secretion. 